\title{
ETHICAL COMPETENCE AS A COPING RESOURCE FOR MORAL DISTRESS IN NURSING
}

\author{
Rafaela Schaefer ${ }^{1}$, Margarida Vieira ${ }^{2}$
}

\begin{abstract}
${ }^{1}$ Doctoral student in Nursing, the Institute of Health Sciences of the Catholic University of Portugal - Porto (UCP). Researcher for the Centre of Interdisciplinary Investigation in Health (CIIS). Porto, Portugal. Email: rafaelaschaefer1988@gmail.com

2 Ph.D. in Philosophy. Associate Professor of the UCP. Researcher for the CIIS. Porto, Portugal. Email: mmvieira@porto.ucp.pt
\end{abstract}

\begin{abstract}
The study's objectives were: to seek evidence on ethical situations experienced by nurses in the health services; to identify the coping resources which they use; and to ascertain the role of ethical competence in coping with moral distress. The integrative literature review was used as the method. The search was made in the LILACS, IBECS, MEDLINE, SciELO, CINAHL, PubMed, RCAAP and BDTD databases. A total of 23 studies was selected, based on previously established inclusion and exclusion criteria. The results indicate ethical questions experienced by the nurses in their relations with patients and family members, the team and the health system. Coping resources used by the professionals and implemented by the researchers are described. It may be concluded that the ethical challenges and moral distress are present in the nurses' work context, and the strategies aimed at promoting ethical competence, have positive consequences in coping with, and in reducing, levels of moral distress.
\end{abstract}

DESCRIPTORS: Ethics. Nursing. Ethical competence. Moral distress.

\section{COMPETÊNCIA ÉTICA COMO RECURSO DE ENFRENTAMENTO DO SOFRIMENTO MORAL EM ENFERMAGEM}

\begin{abstract}
RESUMO: Os objetivos do estudo foram: buscar evidências sobre situações éticas vivenciadas por enfermeiros nos serviços de saúde; identificar os recursos de enfrentamento que utilizam; e verificar qual o papel da competência ética no enfrentamento do sofrimento moral. Utilizou-se como método a revisão integrativa da literatura. A busca foi feita nas bases de dados LILACS, IBECS, MEDLINE, SciELO, CINAHL, PubMed, RCAAP e BDTD. Foram selecionados 23 estudos, a partir de critérios de inclusão e exclusão previamente estabelecidos. Os resultados apontam para questões éticas vivenciadas pelos enfermeiros nas relações com pacientes e familiares, equipe e sistema de saúde. Descrevem-se recursos de enfrentamento protagonizados pelos profissionais e implementados por pesquisadores. Pode-se concluir que os desafios éticos e o sofrimento moral estão presentes na realidade de trabalho dos enfermeiros e que estratégias no sentido de promover a competência ética podem ter reflexos positivos no enfrentamento e na redução dos níveis de sofrimento moral.
\end{abstract} DESCRITORES: Ética. Enfermagem. Competência ética. Sofrimento moral

\section{COMPETENCIA ÉTICA COMO RECURSO PARA COMBATIR SUFRIMIENTO MORAL EN ENFERMERÍA}

\begin{abstract}
RESUMEN: Los objetivos del estudio eran buscar temas éticos experimentados por las enfermeras en los servicios de salud, identificar los recursos de afrontamiento que utilizan, y encontrar cuál es el papel de la competencia ética para sobrellevar el sufrimiento moral. El método se utiliza como una revisión integradora de la literatura. La búsqueda se realiza em LILACS, IBECS, MEDLINE, SciELO, CINAHL, PubMed, RCAAP y BDTD. Fueron seleccionados 23 estudios desde critérios de inclusión y de exclusión. Los resultados apuntan a desafios éticos vivenciados por enfermeros en las relaciones con pacientes, personal y sistema de salud. Describe los recursos de afrontamiento asumidos por los profesionales y puestos en práctica por los investigadores. Se puede concluir que los desafios éticos y el sufrimiento moral están presentes en la realidad del trabajo de las enfermeras y las estrategias para promover la competencia ética puede tener efectos positivos en el afrontamiento de sufrimiento moral.
\end{abstract}

DESCRIPTORES: Ética. Enfermería. Competencia ética. Sufrimiento moral. 


\section{INTRODUCTION}

The growing complexity of work in healthcare, characterized by organizational changes, technological development, financial tension and broadening of the workload, has direct implications for professional practice - and can lead to an important increase in the ethical demand posed by the services. Nurses increasingly experience ethical challenges posed by their practice in the search to provide quality care. ${ }^{1}$

In the light of cultural changes and societal evolution, the role of ethics is being emphasized in the health professions. Ethics has a place in the various ways of analyzing moral life grounded in the perception of conflicts, and in coherence in resolving them ${ }^{2}$ and is, therefore, at the center of the decisions in which the nurses are involved. ${ }^{3}$

In providing care, the nurses establish relationships with patients, family members and work colleagues, becoming involved in a continuous process of interaction with others. Their role and their occupation in the health care team leaves them prone to experiencing ethically problematic situations, when doubts exist regarding the most correct decision to take. ${ }^{1}$

In spite of the growing increase in the ethical demands in decision-making in healthcare, there are few organizational initiatives promoted in order to help the professionals in this process. ${ }^{4}$ The lack of time, the lack of organizational support, the conflicts with other professionals, the institutional policies and the different ethical and legal limits associated with the process of decision-making can lead the nurses to experience what is termed 'moral distress'. ${ }^{5}$

Moral suffering or distress is a serious problem that affects nurses in different contexts of work in healthcare, and which can generate feelings of dissatisfaction, physical and emotional symptoms, fatigue, staff turnover, and even abandonment of the profession, and can lead to an important impact on the quality of the health care. ${ }^{5}$ Even experienced nurses continue to experience situations which cause moral distress in their work, ${ }^{6}$ which demonstrates the continuing need to strengthen professionals' capacity to deal positively with the ethical demands posed by their practice. Ethical competence appears as an important tool for dealing with ethical events and challenges in the routine, as it seeks to help the professionals to deal with ethical demands critically, reflexively and resolutively. ${ }^{7}$

In this context, it becomes important to perceive how nurses are dealing with the ethical demands and the moral distress experienced, in order to propose future strategies for managing moral distress and for later evaluation of the proposals implemented. Thus, this study's objectives were to seek the best evidence available in the literature on the ethical demands experienced by nurses in the health services; to identify the coping resources which they use for responding to this demand; and to ascertain the role of ethical competence in coping with moral distress.

\section{METHOD}

An integrative review of the literature was undertaken, a wide-ranging search method, which seeks to critically analyze the relevant research, indicating the summary of the state of knowledge regarding a specified issue and, also, the gaps which remain to be explored through the undertaking of further studies. As the methodology stipulates, the following stages were undertaken: elaboration of the research question, establishment of the criteria for selecting the studies found, and selection, analysis and interpretation of the results. ${ }^{8}$

In accordance with the first step, the guiding questions for this review were: What are the main ethical demands which nurses experience in the health services? What are the coping resources which they use to respond to this demand? Does developing ethical competence help to reduce the moral distress?

Subsequently, the following were considered as inclusion criteria: original articles, theses and dissertations which had a close relationship to the issue studied, published in English, Spanish or Portuguese, whose research subjects were nurses working in healthcare institutions. No time limit or search limit was established, as it was considered that ethics is an issue which has been part of science since its creation. As a result, the following were excluded: secondary studies and studies in which the research subjects were other health professionals, students, service users or nurses in other work contexts.

To select the studies, a broad search was undertaken in national and international data bases: LILACS (Latin American and Caribbean Center on Health Sciences Information), IBECS (Spanish 
Health Sciences Bibliometric Index), MEDLINE (Medical Literature Analysis and Retrieval System Online), SciELO (Scientific Eletronic Library Online), CINAHL (Cumulative Index to Nursing and Allied Health Literature) and PubMed. In addition, theses and dissertations were sought in the RCAAP (Scientific Open Access Repository of Portugal) and BDTD (Brazilian electronic theses and dissertations digital library) databases. The bibliographic references of the works found were reviewed so as to find further material of interest for this review.

The search was undertaken using the following descriptors/mesh terms: nursing, ethics, ethical competence, ethical problem, moral distress, ethical reasoning and ethical decision making. These terms were combined in different ways using the Boolean operators - AND, OR and NOT, seeking to reach a higher number of studies. Table 1 demonstrates the selection path for the studies.

Table 1 - Selection of studies in the electronic databases

\begin{tabular}{lccccc}
\hline Databases & $\begin{array}{c}\text { Found } \\
\mathbf{n}\end{array}$ & $\begin{array}{c}\text { Pre-selected } \\
\mathbf{n}\end{array}$ & $\begin{array}{c}\text { Excluded due to repetition } \\
\mathbf{n}\end{array}$ & $\begin{array}{c}\text { Excluded subsequent to reading } \\
\mathbf{n}\end{array}$ & $\begin{array}{c}\text { Sample } \\
\mathbf{n}\end{array}$ \\
\hline LILACS & & & & & \\
IBECS & 77 & 44 & 10 & 6 & 4 \\
MEDLINE & & & & & \\
SciELO & & & 9 & 6 & 3 \\
CINAHL & 22 & 14 & 41 & 31 & 10 \\
Pubmed & 102 & 61 & - & 1 & 2 \\
RCAAP & 3 & 3 & - & 4 & 2 \\
BDTD & 6 & 6 & - & - & $\mathbf{4 7}$ \\
References & - & - & $\mathbf{6 0}$ & & 23 \\
\hline Total & $\mathbf{2 1 0}$ & $\mathbf{1 2 8}$ & &
\end{tabular}

Of the 210 studies found, 128 were selected following the application of the inclusion and exclusion criteria previously established. Of these, 60 were excluded because they were repeated in different databases, and the abstracts of 68 were read in full. Following reading, a further 47 studies were excluded, either because they were theoretical $(n=33)$ or because they did not address the issue studied $(n=14)$. At that point, the sample contained 21 studies. A strategy of reverse search was then used, which culminated in the addition of a further two studies, making up a final sample of 23 studies.

Following the selection, the researchers proceeded to the analysis and interpretation of the results. Data collection took place in October - November 2013. The searches were undertaken by two separate researchers and, afterwards, their results were compared, so as to increase the study's validity and ensure that the majority of the works published had been accessed.

\section{RESULTS}

This work's sample is made up of 23 studies (Table 1), of which $19(82.6 \%)$ are original articles, two $(8.7 \%)$ are theses, and a further two $(8.7 \%)$ are dissertations. The majority of the studies were published in English (16;69.6\%), the remainder being published in Portuguese $(7 ; 30.4 \%)$. Studies in Spanish were not found. The studies' countries of origin are divided among the United States of America and Brazil, both with five studies each $(21.8 \%)$, Sweden and Norway, with three studies each $(13.1 \%)$, and Portugal, with two studies $(8.7 \%)$. The other countries, namely Canada, Israel, Turkey, Iran and Holland, produced one study each $(4.3 \%)$.

The majority of the studies $(15 ; 65.2 \%)$ were published in nursing journals, and two studies $(8.7 \%)$ were published in journals of medicine. There was one study published in a bioethics journal, and one in a public health journal (4.3\%). All the journals were considered quality periodicals, with impact factors varying from 0.387 (Journal of the School of Nursing of the University of São Paulo) to 4.083 (American Journal of Bioethics).

No time limit having been established, the studies selected were distributed between 1997 and 2013, varying from one study in 1997 (4.3\%) to four studies in 2013 (17.4\%). The methods used varied between qualitative $(12 ; 52.2 \%)$ and quantitative proposals $(8 ; 34.8 \%)$, with studies with mixed methodology also appearing $(3 ; 13 \%)$. 


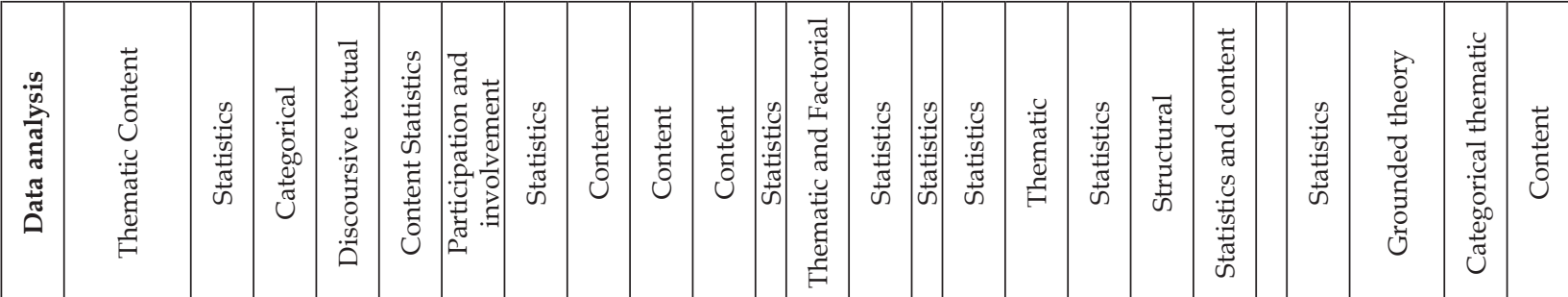

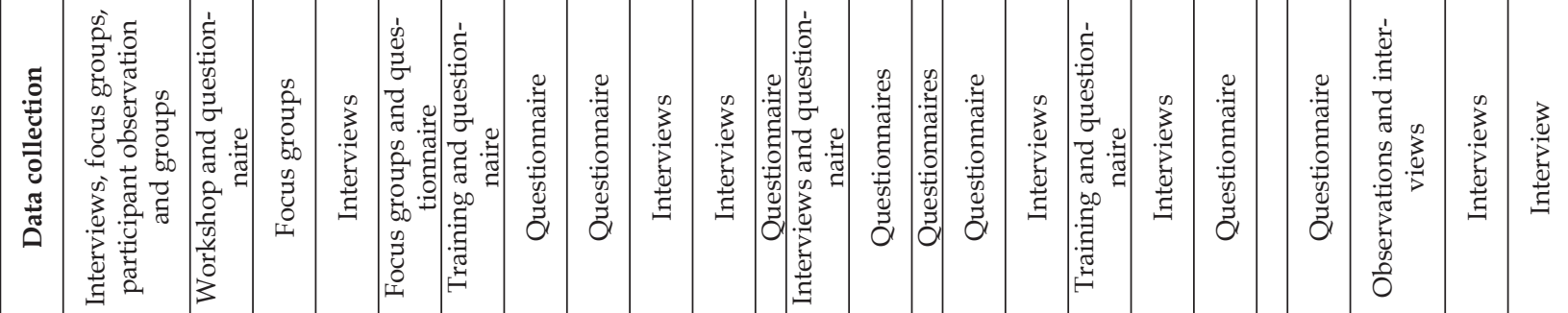

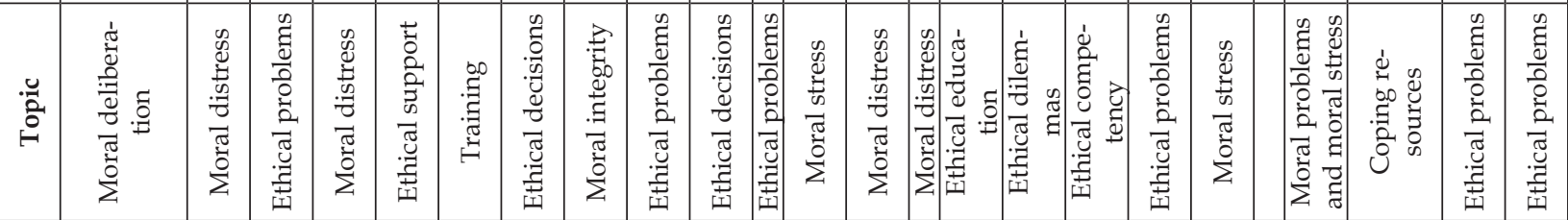

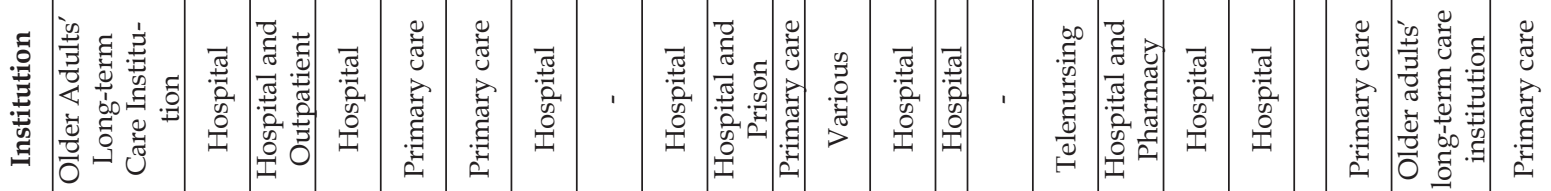

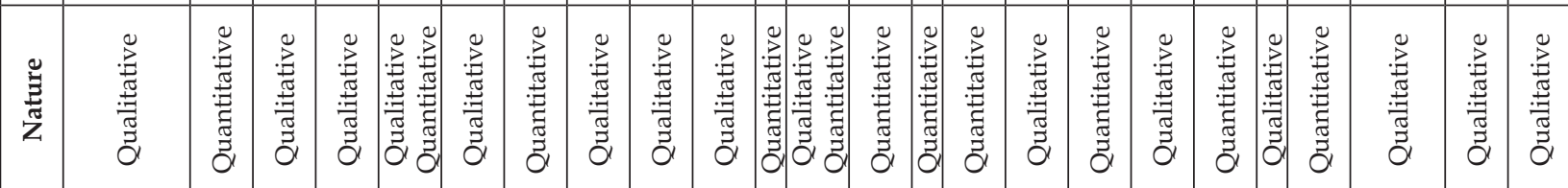

总荽

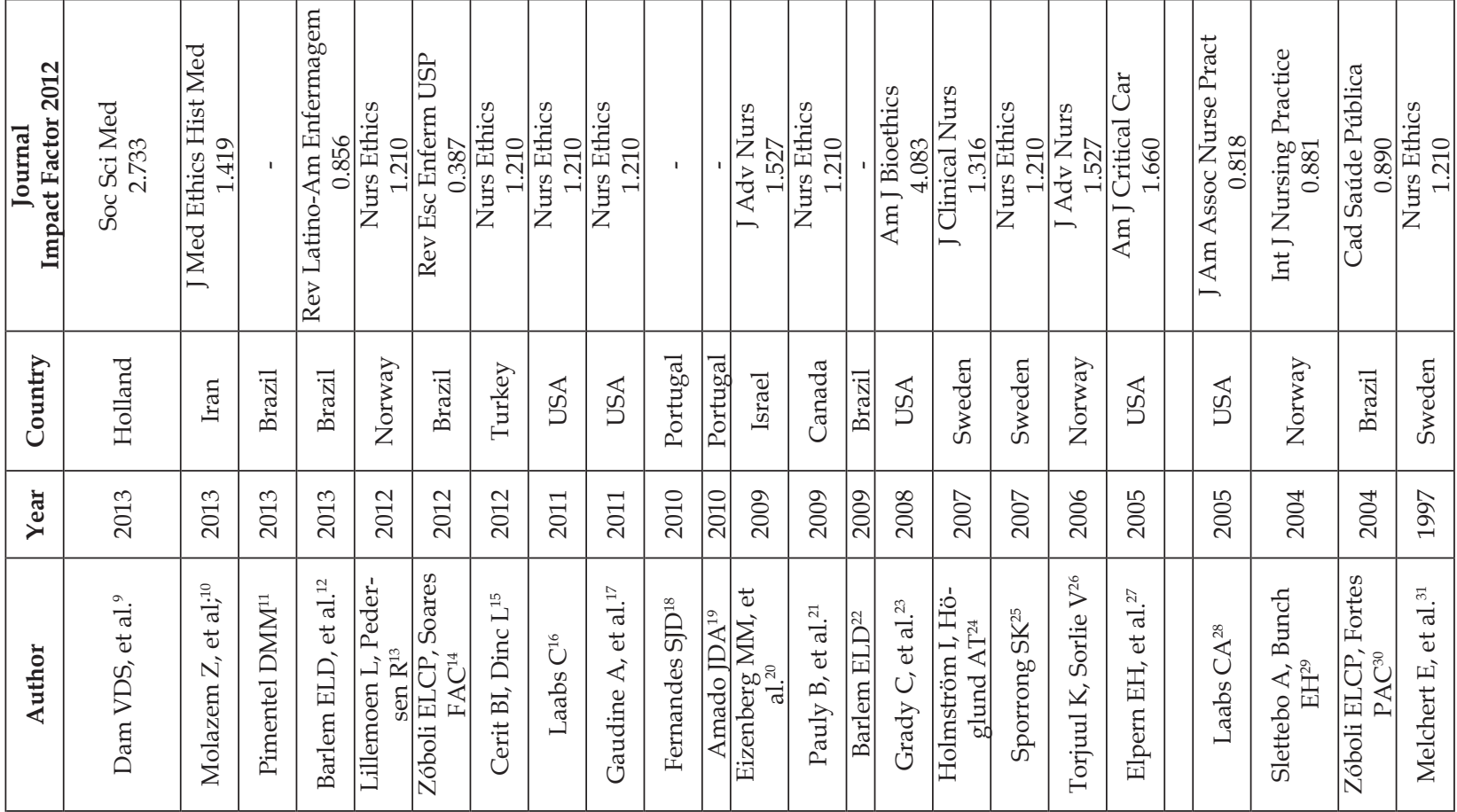


The main data collection methods were the questionnaire $(8 ; 34.8 \%)$ and the interview (7; $30.4 \%)$. A considerable number of studies (7; $30.4 \%)$ used more than one data collection method, associating interviews, questionnaires, groups and others. As the method for analyzing the data, the authors mention the use of different types of qualitative analysis, emphasizing content analysis $(5 ; 21.7 \%)$. Other types of qualitative analysis included thematic analysis $(2 ; 8.6 \%)$, categorical analysis, discoursive textual analysis, structural analysis and grounded theory, all cited once $(4.3 \%)$. Statistical analysis was used in eight studies $(34.8 \%)$. There were also four studies which used more than one method for analyzing data $(17.4 \%)$.

Subsequent to reading the studies, it was possible to divide them by central themes. Some studies present ethical questions experienced by nurses in the health care institutions, others ascertain whether these professionals used some type of coping resource, and others propose intervention strategies. Some studies also point to the relation between these intervention strategies and the professionals' levels of moral distress (Figure 1). Each one of these topics will be addressed below.

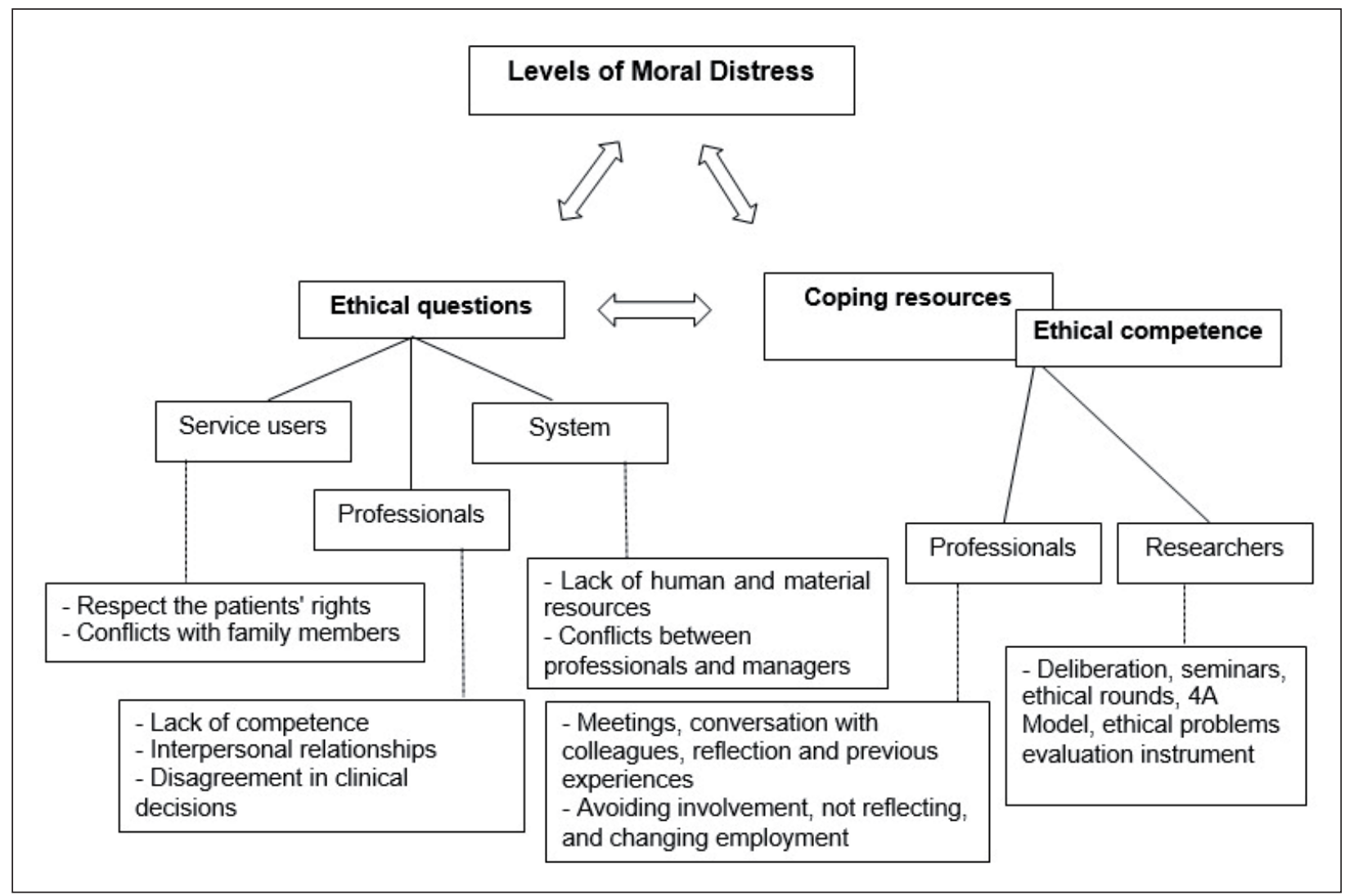

Figure 1 - Diagram of relations between the results

In the issue of ethical questions, articles were included which pointed to the ethical demands experienced by the nurses in their work routine. For many professionals, it is still difficult to perceive the ethical dimension in the work and, often, they experience important ethical questions but do not know what name to attribute, or what meaning to give, to these situations. ${ }^{9-10}$ One study emphasizes the fact that $76 \%$ of professionals interviewed indicated that they never or rarely found ethical situations in their practice. ${ }^{28}$

The studies' results point to ethical questions related to the nurses' work context. On the one hand, there are ethical situations typical of critical care, with questions such as end-of-life care and therapeutic obstinacy. ${ }^{10,17,22,27}$ On the other, there are situations related more to the routine, such as issues of relationships and communication..$^{28}$

Within these contexts, many ethical situations have their place in the ambit of care for the patient ${ }^{10,17-18,22,28-30}$ such as difficulty in respecting the patient's rights, ${ }^{17,22,28,30}$ and conflicts with family members. ${ }^{10,17-18,30}$ Other ethical questions emphasized are lack of quality in end-of-life care, 
the patient's behavior impeding safe care, lack of informed consent, ${ }_{17}^{17}$ refusal to be the patient's advocate, ${ }^{22}$ the patient's refusing of treatment ${ }^{28}$ and disagreements between nurse and patient. ${ }^{29-30}$

In relation to the experiencing of ethical situations with other professionals, emphasis is placed on the lack of competence as a highly frequent and intense problem. ${ }^{10,17,21-22,30}$ Incompetence can result from poor training ${ }^{11}$ and can sometimes promote inadequate patient care. ${ }^{13,26}$ This category also covers situations resulting from interpersonal relationships ${ }^{11}$ and from disagreement regarding the clinical decisions. ${ }^{13,17,26}$ It is also possible to perceive some ethical questions which permeate the patient and professional categories, related to information ${ }^{13,26,30-31}$ and conflicts of values. ${ }^{17}$

In the ethical questions related to the health system, emphasis is placed on the lack of human and material resources, ${ }^{10-11,13,20,26,28-30}$ when the professional does not act as she would like to, as a result of lack of resources and time. ${ }^{13,26}$ Another topic present in this category is the conflict experienced between professionals and health managers. ${ }^{11,31}$

It is possible to perceive that many works reveal ethical questions related to the individual characteristics of the professional who works with a lack of responsibility, ${ }^{13}$ lack of commitment, ${ }^{30}$ lack of confidence, ${ }^{26}$ difficulty communicating ${ }^{11,13}$ and, sometimes, ignorance of what the right thing to do is. ${ }^{17-18,31}$ One study emphasizes the professional autonomy which seems to be correlated with the different categories, as it appears because the nurses need to respect the patient's rights, follow medical prescriptions, and comply with organizational regulations at the same time. ${ }^{15}$

On the topic of coping resources, studies were included in initiatives for coping with the ethical demands experienced, which were undertaken by the professionals themselves or applied by researchers as part of their studies. Of the coping resources used by the professionals, one can perceive that, in the light of the different ethical situations, these can act in two ways, one more positive and the other more negative. Of the positive ways of coping, conversation with work colleagues forms part, $13,16,23$ as do holding meetings, ${ }^{12-13}$ reflection ${ }^{16}$ and the learning obtained from previous experiences..$^{29}$ Also included are changes in protocols, creativity, and collective actions. ${ }^{12}$ On the other hand, the professionals sometimes responded negatively, when they avoided becoming involved in ethically difficult situations and the resolving of these, ${ }^{12,28}$ when they did not discuss or reflect on the case $\mathrm{e}^{13,31}$ or when they opted to change job. ${ }^{28}$ Characteristics of acceptance, conformism, desisting and individualism can also be observed. ${ }^{12}$

Many professionals reported wishing to place greater emphasis on the teaching of ethics, ${ }^{11,31}$ that there were more courses in the work environment ${ }_{1}^{10}$ discussions on the ethical questions experienced $^{16}$ and the creation of ethics committees; ${ }^{10}$ they did not present, however, any initiatives for achieving any of these objectives.

On the other hand, some studies showed data referent to processes of implementation of coping resources proposed by the researchers in the work environments. Two studies show the experience of implementing the model of deliberation in problem resolution. ${ }^{9,14}$ The first proposed groups with the objective of facilitating reflection and moral deliberation through the discussion and analysis of cases ${ }^{9}$ and the other used various methodologies making use - besides discussion and analysis of cases - of plenary sessions, readings, dramatization, classes and written exercises. ${ }^{14}$

One of the studies analyzed undertook an educational intervention in ethics with nurses and pharmacists through seminars and ethical rounds, with the objective of improving the participants' ethical knowledge. ${ }^{25}$ Another implements the $4 \mathrm{~A}$ Model, created by the American Association of Critical-Care Nurses in 2004, which provides a structure for critical-care nurses to identify and deal with moral distress. ${ }^{10}$ Moreover, another study adopted an instrument for evaluating the occurrence of ethical problems, in order to help the professionals perceive what the most frequent ethical questions in their work are. ${ }^{19}$

Other studies suggested coping resources which professionals and institutions could follow in order to deal better with ethical demands, but did not apply them. Ethical education was the resource cited most, ${ }^{20,24,31}$ followed by rounds of ethical discussions ${ }^{24,31}$ and of political actions. ${ }^{21,26}$ Suggestions also appeared for involvement in scientific research, ${ }^{15}$ involvement in deliberative processes ${ }^{21}$ and strengthening of dialogue. ${ }^{26}$

In relation to coping resources, the development of ethical competency and the levels of moral distress, one study used the method of deliberation and showed that, in gaining experience, reflecting on practices and deliberating, the professionals developed competencies and improved communication and the decision-making process, thus contributing to a feeling of relief of moral distress. 
The result was evaluated qualitatively through thematic content analysis. ${ }^{9}$

The same variable - moral distress - was evaluated following the application of the $4 \mathrm{~A}$ Model, it being observed that there was a significant reduction in the levels of moral distress, also showing a tendency for increase of the variable in the control group. This evaluation was made through a validated quantitative instrument for evaluating moral distress, and statistical analysis. ${ }^{10}$ Equally, one of the works did not identify a reduction in the professionals' levels of moral distress, but presented a significant reduction in the levels of tolerance and openness subsequent to the training. This evaluation was made using a validated instrument and statistical analysis. ${ }^{25}$

Another study ${ }^{13}$ mentions that there were positive results arising from the experience of focus groups reflecting on and questioning the practices, but makes no specific mention of moral distress. These observations were collected qualitatively and were evaluated through textual discoursive analysis. ${ }^{11}$

There is also one case which is different from the others, in which the researcher did not implement any coping strategy, but concluded through the statistical analysis of a questionnaire which he had elaborated - that ethical education and training, mainly through continuing education, are vital to provide the nurses with tools for dealing with the ethical demands and to reduce the moral distress. ${ }^{23}$

\section{DISCUSSION}

Ethics is increasingly closer to healthcare practices. The work of nursing, characterized by contexts which become more complex day by day, poses important ethical questions, and it is known that nurses need to be prepared to deal with this demand positively, maintaining the quality of the care provided. ${ }^{32}$

It is important to emphasize that, in spite of ethics' growing closeness to practice, of the articles preselected for reading, approximately $48.5 \%$ $(n=33)$ were excluded for being theoretical, that is, they did not bring empirical facts in their results, but, rather, reflections. This demonstrates that it is still necessary to advance in scientific investigation regarding ethics in healthcare practice.

The difficulty demonstrated by the professionals in perceiving the ethical dimension of the practice $^{9-10}$ evidences a reduced awareness of the ethical dimension of the care, leading to the risk that the care might be reduced simply to technical issues. ${ }^{33}$ Without the ethical dimension, the best technical care may be perceived as low quality and unsatisfactory. ${ }^{14}$ When the professionals are unable to perceive the ethical questions in their practice, there may be breaking of relations, and the professional may end up having to confront complex ethical situations alone, without assistance or guidance. ${ }^{28}$ This statement is corroborated by the results of one of the studies analyzed, ${ }^{10}$ in which the nurses were not familiar with the concept of moral distress and were unable to give a name to the situations which they experienced or to the resultant feelings, although the questionnaire administered revealed the occurrence of high levels of moral distress.

This difficulty in perceiving the ethical dimension of the care may also be the result of the culture of the work and of the organizations, in which dialogue is not common and many controversial issues remain in silence. ${ }^{9}$ Increasing attention has been directed towards organizational culture, through the establishing of a positive ethical climate as a promoter of quality, in which the professionals may be more involved in processes of reflection and deliberation with other colleagues, and through which the service's management provides support to improvement initiatives through the reformulating and adaptation of practices and policies. ${ }^{21}$ However, the literature alerts one to the fact that this type of initiative remains an important challenge in the health care services. ${ }^{25}$

The context in which the ethical questions arise may also influence their incidence and intensity, as shown in studies demonstrating that nurses who work in critical care hospital units are more vulnerable to experiencing ethical issues, and, as a consequence, moral distress, due to dealing with more complex contexts, ${ }^{34}$ new life-support techniques, limitations in predicting death and higher expectations from patients and family members. ${ }^{27}$ Another study, however, contradicts this idea, stating that ethical issues in primary care services focus on concerns regarding the routine, but that this does not mean that they are less important and that, in their own way, they are also broad and complex, although less dramatic. ${ }^{30}$ One can, therefore, perceive that - regardless of the context of the occurrence of the practice's ethical demand - what is important is that each healthcare institution should be aware of the most prevalent issues 
in its context, so that in this way it may be able to provide an appropriate way of resolving these. ${ }^{10}$

Among the ethical questions which emerge from the professional-patient relationship, the nurse's difficulty respecting the patient's wishes and rights is one of the questions cited most. ${ }^{17,28,30}$ The literature explains this finding by saying that there remains, in the health care area, a culture which tends not to recognize the patient as an autonomous subject, who has the ultimate say in making decisions regarding his or her treatment, and it is in this inter-relationship, between the perception of the professional and of the patient, that the ethical challenge lies. ${ }^{22}$ This assertion is corroborated by another study, which calls attention to the relation between ethical issues and possible disrespect for the self-government, freedom, privacy and individual choice of the patient, adding that it is the responsibility of the nurses, as well as of the other professionals of the healthcare team, to expend efforts in order to ensure that the patient's rights are respected. ${ }^{35}$

Conflict with family members is also significantly present in the studies analyzed, addressing different perspectives. In one of the studies, this issue is related to the professional's articulation with the family in relation to the transmission of information, regarding when to provide the truth regarding a diagnosis and when not to. ${ }^{18}$ In the results of another study, however, this conflict seems to be more related to disagreement between nurses and family members, when the patient's wishes are ignored because of requests or demands made by their families. ${ }^{10}$ Also ascertained was the behavior of family members which hinders safe care for the patient or for other patients, or, even, behavior which generates negative impact on the quality of work of the health professionals. ${ }^{17}$ One can conclude the discussion with a perspective which reinforces the importance of being alert to the different ethical questions posed by the practice and of always seeking to resolve these, given that the objective of the professional and of the family member, in relation to the patient, should always be the same - to promote what is best for the patient. ${ }^{16}$

The lack of competence of work colleagues or their bad practice was the ethical challenge found most among the professionals. This finding supports the results of other studies of the area, ,,36-38 and has to do with the lack of skill or technical competence the professionals should have in undertaking care actions. ${ }^{22}$
In the context of the health care organizations, the lack of human and material resources is perceived by the professionals as one of the biggest causes of ethical challenges, as it makes the work load heavy and creates difficulty for the nurse, who has to determine which patients must be attended and to which patients she must give more attention - as she knows that in so doing she could be harming others. ${ }^{26}$ In contexts which are impaired by the lack of resources, the professionals feel a lack of time for practicing care of a quality which they would like, and feel that the patients are not receiving the care to which they have a right. ${ }^{12}$ This is highly distressing and leads the professionals to experience high levels of moral distress, impacting the quality of the care. ${ }^{5}$

When these ethical questions are not perceived, and nothing is done in relation to understanding and resolving them, the professionals can experience moral distress, ${ }^{39}$ which may intensify if there are no effective interventions, creating consequences for professionals, patients and institutions. ${ }^{10}$ Although the health professionals' moral distress seems inevitable, measures can be taken to improve their capacity to deal with such difficult experiences and their ability to resolve stressful situations constructively and ethically. ${ }^{20}$ Interventions proposed can be more effective if they take into account issues referent to the professionals' values, their educational process, and - mainly - the specific characteristics of the services in which they work. ${ }^{40}$

In this regard, dialogue with colleagues, ${ }^{13,16,23}$ the organizing of meetings ${ }^{12-13}$ and reflection ${ }^{16}$ can enable nurses to deal with ethical demands, and to bring positive results for the professional, in terms of prevention or reduction of moral distress, for the patients, in terms of quality of care, and for the institution, in terms of efficacy and results. 3,10,25 However, many professionals can have problems in dealing with ethical issues, and present negative ways of coping, such as accepting and conforming to situations, which may be a reflection of the profession's culture, which relates being a nurse to personal sacrifice for the good of others, naturalizing professional suffering and causing the omission to appear to be a good strategy. ${ }^{12}$

This difficulty presented by the nurses for responding to ethical issues posed by their practice may also be a reflection of the organizational culture which does not encourage the perceiving of, and reflecting on, the problems ${ }^{10}$ or may be the result of insufficient ethical training. ${ }^{11,23}$ When the nurses are unable to deal with an ethical demand, 
they may experience moral distress which can lead to dissatisfaction, rage, isolation, anxiety, depression, changing department or job, or leaving the profession, causing consequences for aspects of quality and satisfaction with the care. ${ }^{41}$

In this perspective, many of the studies analyzed raise proposals for interventions, with the aim of helping the professionals to perceive the ethical challenges posed by the practice, and to dialogue and reflect on these issues, thus seeking the best way of resolving them. Studies report the results of the application of models of deliberation and, in spite of using different strategies of application, concluded that the ethical deliberation model is positive and promotes professional competence. ${ }^{9,14}$ The literature corroborates the positive perspective of the model of deliberation, and adds that during the deliberative process it is important that all the professionals should participate, respect each other's opinions, adopt a collective perspective, and provide rationales for the ideas proposed. ${ }^{42}$

The proposals which seek to enable the nurses to perceive the ethical nature of the challenges they experience in their work ${ }^{19}$ or, furthermore, which seek to help the professionals to identify and deal with moral distress, ${ }^{10}$ have positive results both in the development of competency and in the reduction of the moral distress. Positive results caused by ethical training initiatives appear in studies through the undertaking of seminars and the application of ethical rounds. ${ }^{25}$ In accordance with these findings are other studies which confirm that all interventions in ethical training are valid, even if they do not achieve the expected results, as the fact of working on and discussing the issue in itself broadens horizons and encourages positive ethical attitudes on the part of the professionals and the organizations. ${ }^{43-44}$

In reflecting on the practice, the professionals develop competencies, and this is related to the quality of the care; for this reason, it is important to apply proposals for interventions and to encourage the organizations to perceive the main causes of moral distress - and to work towards reducing and preventing these. ${ }^{10}$ The literature, however, suggests that interventions are only effective if the organizations' ethical dimension is also developed, as it is necessary for this to take responsibility for leading reflection and resolution of their staff's ethical cases, as individual interventions undertaken in isolation, or short-term interventions, seem not to function. ${ }^{25}$

\section{CONCLUSIONS}

The ethical demands posed by the practice, and the consequent moral distress, are highly present realities in the work of nurses from different health services. In order to deal with these issues, the professionals use different coping resources, which can be positive when they lead to dialogue and to reflection, or negative, when they cause the professional to accept and conform to the context, experiencing difficult ethical situations alone, without the support of colleagues or the institution, and being prone to a feeling of moral distress.

Initiatives can be organized to help the professionals and to develop their ethical competence, and, thus, deal better with ethical challenges. In this regard, it is important that each institution should perceive what the issues are that most generate moral distress among their workers, and what type of intervention adapts best to their context, in order for the results to be efficacious.

Ethical education, problematized teaching, moral deliberation, dialogue, reflection, the undertaking of studies and encouraging nurses to participate in this process can help to promote the workers' ethical competence. Ethically competent professionals have greater skill in coping with the ethical questions posed by practice and, as a result of this, are better able to deal with the moral distress and its consequences.

This review brings a consistent sample of studies in the area of ethics in nursing, from journals of scientific quality, with high impact factors. The study was shown to be broad, and was able to bring together articles from different decades, and demonstrate the growing tendency for publication of original works in this area. In spite of this, further research in this issue is necessary, in order to understand better this process of coping with problems and to serve as a basis for developing efficacious tools for reducing moral distress, thus avoiding its consequences.

\section{REFERENCES}

1. Redman BK, Fry S. Nurses' ethical conflicts: what is really known about them? Nurs Ethics [online]. 2000 Jul [acesso 2013 Nov 05] 7(4):360-6. Disponível em: http:/ / dx.doi.org/10.1177/096973300000700409

2. Segre M, Cohen $C$, organizadores. Bioética. São Paulo (SP): EDUSP; 2002.

3. Mendes G. A dimensão ética do agir e as questões da qualidade colocadas face aos cuidados de enfermagem. Texto Contexto Enferm [online]. 
2009 Jan-Mar [acesso 2015 Mar 06]; 18(1):165-9. Disponível em: http://dx.doi.org/10.1590/S010407072009000100020

4. Corley MC, Minick P, Elswick RK, Jacobs M. Nurse moral distress and ethical work environment. Nurs Ethics [online]. 2005 Jul [acesso 2013 Nov 18]; 12(4):381-90. Disponível em: http://dx.doi.org/ doi:10.1191/0969733005ne809oa

5. Burston AS, Tuckett AG. Moral distress in nursing: contributing factors, outcomes and interventions. Nurs Ethics [online]. 2013 May [acesso 2013 Out 29]; 20(3):312-24. Disponível em: http:/ / dx.doi.org/ doi:10.1177/0969733012462049

6. Corley MC. Nurse moral distress: a proposed theory and research agenda. Nurs Ethics [online]. $2002 \mathrm{Nov}$ [acesso 2013 Nov 21]; 9(6):636-50. Disponível em: http://dx.doi.org/doi:10.1191/0969733002ne557oa

7. Paganini MC, Egry EY. The ethical component of professional competence in nursing: an analysis. Nurs Ethics [online]. 2011 Jul [acesso 2012 Jun 22]; 18(4):571-82. Disponível em: http://dx.doi.org/ doi:10.1177/0969733011408041

8. Polit DF, Beck CT. Fundamentos de pesquisa em Enfermagem: avaliação de evidência para a prática da enfermagem. $7^{\text {a }}$ ed. Porto Alegre (RS): Artmed; 2011.

9. Dam SVD, Schols JMGA, Kardol TJM, Molewijk BC, Widdershoven GAM, Abma TA. The Discovery of deliberation. From ambiguity to appreciation through the learning process of doing Moral Case Deliberation in Dutch elderly care. Soc Sci Med [online]. 2013 Apr [acesso 2013 Nov 13]; 83:12532. Disponível em: http://dx.doi.org/10.1016/j. socscimed.2013.01.024

10. Molazem Z, Tavakol N, Sharif F, Keshavarzi S, Ghadakpour S. Effect of education based on the "4A Model" on the Iranian nurses' moral distress in CCU wards. J Med Ethics Hist Med [online]. 2013 Apr [acesso 2013 Nov 11]; 6(5):[8 telas]. Disponível em: http://www.ncbi.nlm.nih.gov/pmc/articles/ PMC3740193/

11. Pimentel D. A ética das relações: percepção de médicos e enfermeiros sobre os conflitos na prática profissional [tese]. Aracajú (SE): Universidade Federal de Sergipe. Programa de Pós-Graduação em Ciências da Saúde; 2013.

12. Barlem ELD, Lunardi VL, Lunardi GL, Tomaschewski-Barlem JG, Silveira RS. Sofrimento moral no cotidiano da enfermagem: traços ocultos de poder e resistência. Rev. Latino-Am. Enfermagem [online]. 2013 Jan-Fev [acesso 2013 Nov 06]; 21(1):293-9. Disponível em: http:/ / www.scielo.br/ pdf/rlae/v21n1/pt_v21n1a02.pdf

13. Lillemoen L, Pedersen R. Ethical challenges and how to develop support in primary health care. Nurs Ethics [online]. 2013 Feb [acesso 2013 Nov 10]; 20(1):96-108. Disponível em: http:/ / dx.doi.org/ doi:10.1177/0969733012452687
14. Zoboli ELCP, Soares FAC. Capacitação em bioética para profissionais da Saúde da Família do município de Santo André, SP. Rev Esc Enferm USP [online]. 2012 Out [acesso 2013 Nov 11]; 46(5):1248-53. Disponível em: http://dx.doi.org/10.1590/S008062342012000500029

15. Cerit B, Dinç L. Ethical decision-making and professional behavior among nurses: a correlational study. Nurs Ethics [online]. 2013 Mar [acesso 2013 Nov 11]; 20(2):200-12. Disponível em: http:/ / dx.doi. org/10.1177/0969733012455562

16. Laabs C. Perceptions of moral integrity: contradictions in need of explanation. Nurs Ethics [online]. 2011 May [acesso 2013 Nov 15]; 18(3):431-40. Disponível em: http://dx.doi. org/10.1177/0969733011398101

17. Gaudine A, LeFort SM, Lamb M, Thorne L. Clinical ethical conflicts of nurses and pshysicians. Nurs Ethics [online]. 2011 Jan [acesso 2013 Nov 06]; 18(1):9-19. Disponível em: http://dx.doi.org/ doi:10.1177/0969733010385532

18. Fernandes SJD. Decisão ética em enfermagem: do problema aos fundamentos para o agir [tese]. Porto (PT): Universidade Católica Portuguesa. Instituto de Ciências da Saúde; 2010.

19. Amado JDN. Avaliação da ocorrência de problemas éticos em cuidados de saúde primários [dissertação]. Porto: Universidade Católica Portuguesa. Instituto de Ciências da Saúde; 2010.

20. Eizenberg MM, Desivilya HS, Hirschfeld MJ. Moral distress questionnaire for clinical nurses: instrument development. J Adv Nurs [online]. 2009 Nov [acesso 2013 Nov 10]; 65(4):885-92. Disponível em: http:/ / dx.doi.org/10.1111/j.1365-2648.2008.04945.x

21. Pauly B, Varcoe C, Storch J, Newton L. Registered nurses' perceptions of moral distress and ethical climate. Nurs Ethics [online]. 2009 Sep [acesso 2013 Nov 11]; 16(5):561-73. Disponível em: http:/ / dx.doi. org/10.1177/0969733009106649

22. Barlem ELD. Vivência do sofrimento moral no trabalho da enfermagem: percepção da enfermeira [dissertação]. Rio Grande (RS): Universidade Federal do Rio Grande. Programa de Pós-Graduação em Enfermagem; 2009.

23. Grady C, Danis M, Soeken KL, O'Donnell P, Taylor C, Farrar A, et al. Does ethical education influence the moral action of practicing nurses and social workers? Am J Bioeth [online]. 2008 Apr [acesso 2013 Nov 12]; 8(4):4-11. Disponível em: http://dx.doi. org/10.1080/15265160802166017

24. Holmström I, Höglund AT. The faceless encounter: ethical dilemmas in telephone nursing. J Clinic Nurs [online]. 2007 Oct [acesso 2013 Nov 06]; 16(10):186571. Disponível em: http://dx.doi.org/10.1111/ j.1365-2702.2006.01839.x

25. Sporrong SK, Arnetz B, Hansson MG, Westerholm P, Höglund AT. Developing ethical competence in 
health care organizations. Nurs Ethics [online]. 2007 Nov [acesso 2013 Nov 10]; 14(6):825-37. Disponível em: http://dx.doi.org/10.1177/0969733007082142

26. Torjuul K, Sorlie V. Nursing is different than medicine: ethical difficulties in the process of care in surgical units. J Adv Nurs [online]. 2006 Jun [acesso 2013 Nov 12]; 56(4):404-13. Disponível em: http:/ / dx.doi.org/10.1111/j.1365-2648.2006.04013.x

27. Elpern EH, Covert B, Kleinpell R. Moral distress of staff nurses in a medical intensive care unit. Am J Crit Care [online]. 2005 Nov [acesso 2013 Nov 06]; 14(6):523-30. Disponível em: http:// ajcc. aacnjournals.org/content/14/6/523.long

28. Laabs C. Moral problems and distress among nurse practitioners in primary health care. J Am Academy of Nurse Practioners [online]. 2005 Feb [acesso 2013 Nov 6]; 17(2):76-84. Disponível em: http://dx.doi. org/10.1111/j.1041-2972.2005.00014.x

29. Slettebo A, Bunch EH. Ethics in nursing homes: experience and casuistry. Int J Nursing Practice [online]. 2004 Jul [acesso 2013 Nov 12]; 10(4):159-65. Disponível em: http://dx.doi.org/10.1111/j.1440172X.2004.00477.x

30. Zoboli ELCP, Fortes PAC. Bioética e atenção básica: um perfil dos problemas éticos vividos por enfermeiros e médicos do Programa Saúde da Família, São Paulo, Brasil. Cad Saúde Pública [online]. 2004 Nov-Dez [acesso 2013 Nov 11]; 20(6):1690-9. Disponível em: http://dx.doi. org/10.1590/S0102-311X2004000600028

31. Melchert E, Udén G, Norberg A. Retired registered nurses' stories about being in ethical difficult care situations. Nurs Ethics [online]. 1997 Mar [acesso 2013 Nov 11]; 4(2):123-34. Disponível em: http:/ / dx.doi.org/10.1177/096973309700400204

32. Fairchlid RM. Practical ethical theory for nurses responding to complexity in care. Nurs Ethics [online]. 2010 May [acesso 2013 Nov 05]; 17(3):353-62. Disponível em: http://dx.doi. org/10.1177/0969733010361442

33. Vanlaere L, Coucke T, Gastmans C. Experiential learning of empathy in a care-ethics lab. Nurs Ethics [online]. 2010 May [acesso 2013 Nov 18]; 17(3):325-36. Disponível em: http://dx.doi. org/10.1177/0969733010361440

34. Pendry PS. Moral Distress: recognizing it to retain nurses. Nurs Economics [online]. 2007 Jul-Aug [acesso 2013 Nov 18]; 25(4):217-21. Disponível em: http://www.ncbi.nlm.nih.gov/pubmed/17847657

35. Chaves PL, Costa VT, Lunardi VL. A enfermagem frente aos direitos de pacientes hospitalizados. Texto Contexto Enferm [online]. 2005 Jan-Mar [acesso 2013 Nov 09]; 14(1):38-43. Disponível em: http:/ / dx.doi. org/10.1590/S0104-07072005000100005

36. Zuzelo PR. Exploring the moral distress of registered nurses. Nurs Ethics [online]. 2007 May [acesso 2013 Nov 18]; 14(3):344-59. Disponível em: http:/ / dx.doi. org/10.1177/0969733007075870

37. Jenkins CL, Elliott AR, Harris JR. Identifying ethical issues of the Department of the Army civilian and Army Nurse Corps certified registered nurse anesthetists. Mil Med [online]. 2006 Aug [acesso 2015 Mar 12]; 171(8):762-9. Disponível em: http:/ /www. ncbi.nlm.nih.gov/pubmed/16933819

38. Fry S, Duffy M. Ethical issue in clinical practice: a multi-state study of practicing registered nurses. ICN Centen Conf. London (UK) [online]; 1999 [acesso 2013 Out 30]; Disponível em: http://jmrileyrn. tripod.com/nen/research.html\#anchor195458

39. Jameton A. A reflection on moral distress in nursing together with a current application of the concept. Bioethical Inquiry [online]. 2013 Sep [acesso 2013 Nov 05]; 10:297-308. Disponível em: http:/ / dx.doi. org/10.1007/s11673-013-9466-3

40. Schaefer R. A construção da competência ética na atenção primária: o caso da enfermagem [dissertação]. São Leopoldo(RS): Universidade do Vale do Rio dos Sinos. Programa de Pós-Graduação em Saúde Coletiva; 2012.

41. Cronquist A, Nyström M. A theoretical argumentation on the consequences of moral stress. J Nursing Management [online]. 2007 May [acesso 2013 Nov 05]; 15(4):458-65. Disponível em: http:/ / dx.doi.org/10.1111/j.1365-2834.2007.00764.x

42. De Vries R, Stanczyk A, Wall IF, Uhlmann R, Damschroder LJ, Kim SY. Assessing the quality of democratic deliberation: a case study of public deliberation on the ethics of surrogate consent for research. Soc Sci Med [online]. 2010 Jun [acesso 2013 Dez 09]; 70(12):1896-903. Disponível em: http:/ / dx.doi.org/10.1016/j.socscimed.2010.02.031

43. Davis S, Schrader V, Belcheir MJ. Influences of ethical beliefs and the impact on moral distress and conscientious objection. Nurs Ethics [online]. 2012 Nov [acesso 2013 Out 29]; 19(6):738-49. Disponível em: http://dx.doi.org/10.1177/0969733011423409

44. Ham K. Principled thinking: a comparison of nursing students and experienced nurses. J Contin Educ Nurs [online]. 2004 Mar-Apr [acesso $2013 \mathrm{Nov}$ 12]; 35(2):66-73. Disponível em: http://www.ncbi. nlm.nih.gov/pubmed/15070189 